\title{
Management of ectomycorrhizal symbionts associated to useful exotic tree species to improve reforestation performances in tropical Africa
}

\author{
Amadou M. B $\hat{A}^{1,3}$, Abdala G. DiÉDHIOU ${ }^{2}$, Yves PRIN ${ }^{4}$, Antoine GALIANA ${ }^{4}$, Robin DuPONNOIS ${ }^{1,2 *}$ \\ ${ }^{1}$ IRD, Laboratoire des Symbioses Tropicales et Méditerranéennes (LSTM), UMR 113 CIRAD/INRA/IRD/SupAgro/UM2, \\ Campus International de Baillarguet, TA A-82/J, Montpellier, France \\ ${ }^{2}$ Laboratoire Commun de Microbiologie IRD/ISRA/UCAD, Centre de Recherche de Bel Air, BP 1386, Dakar, Sénégal \\ ${ }^{3}$ Laboratoire de Biologie et Physiologie Végétales, Faculté des Sciences Exactes et Naturelles, Université des Antilles et de la Guyane, BP 592, \\ 97159 Pointe-à-Pitre, Guadeloupe, France \\ ${ }^{4}$ CIRAD, Laboratoire des Symbioses Tropicales et Méditerranéennes (LSTM), UMR 113 CIRAD/INRA/IRD/SupAgro/UM2, \\ Campus International de Baillarguet, TA A-82/J, Montpellier, France
}

(Received 26 May 2009; accepted 17 September 2009)

Keywords:

arbuscular mycorrhizae /

Casuarinaceae /

Dipterocarpaceae /

ectomycorrhizae /

inoculation /

Leguminosae /

Myrtaceae /

nitrogen fixing bacteria /

Pinaceae

\begin{abstract}
- The objective of this review was to summarize scientific data on the symbiotic status of exotic tree species useful in tropical Africa, and to update reports about their growth improvement through microbial inoculations, especially ectomycorrhizal symbionts.

- The studies reviewed microbial symbionts associated to exotic tree species belonging to Myrtaceae, Pinaceae, Casuarinaceae and Leguminosae. In their native areas, these trees are associated either with ectomycorrhizal (ECM) fungi (e.g. Pinaceae) or both ECM and arbuscular mycorrhizal (AM) fungi (e.g. Eucalyptus), or sometimes as in Casuarina and Acacia with three coexisting symbionts (nitrogen fixing bacteria, ECM and AM fungi). In their new habitats, using highly efficient mycorrhizal fungi, controlled mycorrhization experiments have pointed out the importance of root symbionts in establishment and growth of exotic tree species such exotic pines or Australian acacias.

- Since the challenge in sylviculture and reforestation was to determine the best compromise between symbiotic compatibility and efficiency of both partners under local soil constraints, further researches have to be encouraged to elucidate the complexity of these tree symbioses in terms of diversity, interaction and effectiveness of their symbiotic partners for their better exploitation in reforestation programmes.
\end{abstract}

\author{
Mots-clés : \\ mycorhize à arbuscules / \\ Casuarinaceae / \\ Dipterocarpaceae / \\ ectomycorhizes / \\ inoculation ectomycorhizienne / \\ Leguminosae / \\ Myrtaceae / \\ bactéries fixatrices d'azote / \\ Pinaceae
}

\footnotetext{
*Corresponding author: Robin.Duponnois@ird.fr
} 


\section{INTRODUCTION}

In tropical Africa, two pedoclimatic zones can be distinguished: humid tropics with dense rainforests or gallery forests, and dry tropics with open bush woodlands, savannas, arid steppes (Garbaye et al., 1988; Le Tacon et al., 1989). In the first ecological zone, where water resources are not a limiting factor for tree growth, forestry is often turned to promote high productivity of timber species by genetic selection, clonal propagation, and use of fast growing exotic species (Khasa and Bousquet, 1995). Therefore high value industrial plantations (e.g. pines, acacias and eucalypts) have been implanted in many humid tropical African areas. In the second ecological zone, where dryness naturally keeps down timber productivity, reforestation is a vital need as the forests are at the basis of population survival, through firewood, non-timber products, soil stabilization. However, the success of reforestation programs required a selection of locally adapted plant species (e.g. fast growing, tolerant of dryness, salinity, heavy metal toxicity) able to face drastic conditions and thus to provide improved environmental situation (Smith and Read, 2008). In this context, exotic trees species belonging to Myrtaceae, Pinaceae, Casuarinaceae and Leguminosae were often used.

In their native areas, these exotic tree species are associated with symbiotic microorganisms (mycorrhizal fungi and nitrogen fixing bacteria) which play a significant role in survival and growth of trees. Therefore, the success of tree establishment in a new area involves the availability of functional compatible symbiotic partners. This was convincingly illustrated by the unsuccessful attempts to introduce exotic pines in the tropics until the necessary symbiotic ECM fungi were introduced (Mikola, 1970). Subsequently, seedling inoculation with natural inoculants (soil, crushed fruitbodies or excised ECM roots) has been applied in many tropical African countries to introduce exotic tree species (Garbaye, 1991). However, this practice did not always give best results in growth improvement of exotic tree species in their new habitats, due to the competition between the introduced symbiotic partners and local soil microorganisms (Kabre, 1982; Marx et al., 1985). Hence, to optimize the growth of exotic tree species, use of competitive and effective symbiotic microbial strains was required (Garbaye, 1991; Lamhamedi and Fortin, 1991; Rincón et al., 2007). In this context, the challenge in sylviculture and reforestation was to determine the best compromise between symbiotic compatibility and efficiency of both partners under local soil constraints. This however involves a knowing of symbiotic partners of exotic tree species both in their introduction and native areas.

In this respect, we propose here to review the symbiotic status of exotic tree species useful in reforestation in tropical Africa, and to update reports about their growth improvement through microbial inoculations, specially including ectomycorrhizal ones.

\section{PINACEAE}

In West Africa, the tropical pine species native of Southeast Asia (e.g. Pinus kesiya), Carribean archipelago (e.g.
P. caribaea var. caribaea), Central America (e.g. P. strobus) and North America (e.g. P. radiata) are far the most planted species. These pines are obligate ectotrophs unable to survive or to have a normal growth without symbiotic ECM partners (Delwaulle et al., 1987; Marx et al., 1985; Zhu et al., 2008). Most of their fungal symbionts (Rhizopogon spp., Suillus spp.) are highly host specific, even though some others such as those belonging to the genus Pisolithus may have a broad range of hosts (Bruns et al., 2002; Martin et al., 2002; Marx, 1977; Molina and Trappe, 1994).

$P$. radiata was the first pine species introduced in Kenya in 1902. However, its seedlings were scrubby and had hardly survived the nursery stage. This failure was only solved in 1910 when the Royal Botanical garden in Kew suggested importing some soil, bearing fungal propagules, harvested under ancient pine plantations from South Africa. Successfully used in Kenya this practice was then generalized in several other countries such as Tanzania, Uganda, Zimbabwe, Zambia and Malawi (Mikola, 1970). In West Africa, the first successful pine (P. kesiya) plantations were obtained in Dalaba (Guinea) in 1914. Their associated ECM fungus was identified as a Rhizopogon, which thought to be pine-specific (Delwaulle et al., 1987; Molina and Trappe, 1994). Later, the soil inoculation practice was applied to successfully introduce pines in Cameroon, Congo, Nigeria, Liberia, Ivory Coast and Ghana (Delwaulle et al., 1987; Marx, 1980; Momoh and Gbadegesin, 1980). It is still unclear how the original nursery saplings were first inoculated. Three hypotheses, non exclusive, were proposed to explain the inoculum origin: (i) planted pines would have been introduced as ornamentals, by migrants coming from European countries; (ii) pine seeds would have harboured fungal spores; and (iii) planted pines fungi would have contracted symbiotic relationships with local ECM fungi. However, due to the symbiotic incompatibility between introduced pines and some indigenous ECM fungi (Bâ, 1990), the third hypothesis seems unlikely. This could be supported by the failure to introduce $P$. caribaea in Casamance (South Senegal) where the environmental conditions seemed to be cost attractive to the development of this pine species (Delwaulle, 1978; Kabre, 1982).

Garbaye (1991) reviewed the advantages and disadvantages of the use of natural inoculants (e.g. soil from old plantations, fruitbodies, spores). Indeed, if they are costly attractive compared to the pure strain inoculants, natural inoculants are also a way of parasite dissemination. Therefore, use of pure cultures of selected ECM fungi remains the best practice to optimize the efficiency of inoculums for improvement of tree growth (Lamhamedi and Fortin, 1991; Rincón et al., 2007). This was repeatedly illustrated in pine nurseries and plantations in a range of situations (Tab. I). As an example Momoh and Gbadegesin (1980) and later Delwaulle et al. (1982) reported a better growth response of $P$. caribeae inoculated with a pure Pisolithus tinctorius strain than those with a soil from pine plantations. Nevertheless, this case did not always occur as instanced by Kabre (1982) and Marx et al. (1985). These authors showed that selected fungal strains were less efficient than natural soil inoculants. According to Kabre (1982), the higher efficiency of natural soil inoculants may 
Table I. Controlled ectomycorrhization of Pinus caribaea introduced in Central and West Africa.

\begin{tabular}{|c|c|c|c|c|}
\hline Localities & Measured parameter & Fungal inoculant & $\begin{array}{l}\text { Inoculation effect (compared } \\
\text { to the uninoculated treatment) }\end{array}$ & References \\
\hline Nigeria & Height (after 30 month plantation) & Pisolithus tinctorius & $\times 1.2$ to 2.8 & Momoh and Gbadegesin (1980) \\
\hline \multirow[t]{3}{*}{ Ghana } & Height (after 18 month plantation) & Pisolithus tinctorius & $\times 0.6$ to 1 & Ofosu-Asiedu (1980) \\
\hline & & Rhizopogon luteolus & $\times 1$ & \\
\hline & & Thelephora terrestris & $\times 0.8$ to 1.2 & \\
\hline \multirow[t]{3}{*}{$\mathrm{DRC}^{a}$} & Height (after 20 month plantation) & Pisolithus tinctorius & $\times 1.2$ to 1.5 & Delwaulle et al. (1982) \\
\hline & & Suillus bovinus & $\times 1.1$ & \\
\hline & & Suillus bevini & $\times 1$ & \\
\hline Senegal & Aerial biomass after 8 month plantation & Pisolithus tinctorius & $\times 1.4$ to 13.5 & Kabre (1982) \\
\hline \multirow[t]{2}{*}{ Liberia } & Aerial volume after 3 y plantation & Pisolithus tinctorius & $\times 1.5$ & Marx et al. (1985) \\
\hline & & Thelephora terrestris & $\times 1$ & \\
\hline DRC & Height (after 12 month plantation) & Pisolithus tinctorius & $\times 1.2$ & Delwaulle et al. (1987) \\
\hline
\end{tabular}

${ }^{a}$ Democratic Republic of Congo.

result from the presence of antagonistic soil actinomycetes against the introduced Pisolithus strains. However, in many cases Pisolithus was shown as the most efficient genus for tropical pines (Le Tacon et al., 1989).

\section{MYRTACEAE}

This family comprises 3000 species gathered in 130 genera. Several genera are known as ectomycorrhizal among which Eucalyptus, Melaleuca and Syzygium. African native species all belong to the genus Syzygium (Aubréville, 1950). Eucalyptus and Melaleuca genera are native from Australia, Indonesia and Papua New Guinea but have been introduced in the whole tropics, particularly in Africa. Eucalyptus which is the most planted tree genus in the world includes five subgenera: Monocalyptus, Symphomyrtus, Corymbia, Eudesmia and Idiogenes (Chilvers, 1972). In their native areas, eucalypts contract both arbuscular and ectomycorrhizal symbioses. Among the different subgenera, Monocalyptus (including E. fastigata and E. radiata) and Symphomyrtus (including E. camaldulensis and E. grandis) contain the most ectotrophic species (Chilvers, 1972). According to Chilvers (1972), the diversity of associated ECM fungi would be greater within the Monocalyptus subgenus than within Symphomyrtus. This higher ECM diversity could explain the ability of Monocalyptus to colonize relatively poorer soils than Symphomyrtus (Pryor and Johnson, 1971).

The ECM fungal partners of eucalypts are highly diversified, including both epigeous fungi (e.g. Laccaria laccata, Scleroderma laeve, $P$. tinctorius) with a wide host spectrum and hypogeous fungi (e.g. Hymenogaster albellus, Hydnangium carneum) with a narrower host spectrum (Castellano and Bougher, 1994; Chen et al., 2007; Malajczuk et al., 1982; Tedersoo et al., 2007). The ECM fungi associated to eucalypts include numerous taxa native from African hardwoods or from
American conifers (Chen et al., 2007; Malajczuk et al., 1982; Tedersoo et al., 2007). However, eucalypts would not be compatible with some fungal genera such as Rhizopogon and Suillus generally specific to pines (Malajczuk et al., 1982; Molina and Trappe, 1994). One of the best known eucalypt-associated fungal genera is Pisolithus and its infra-specific diversity was assessed to identify the most efficient isolates promoting eucalypt growth (Aggangan et al., 1996a; Burgess et al., 1994b). Burgess et al. (1994a) and then Martin et al. (2002) reported a large genotypic diversity among Pisolithus. This genotypic diversity was also established at the functional level through eucalypt growth responses to inoculation with Pisolithus isolates from various geographical origins (Aggangan et al., 1996b; Burgess et al., 1994b). The largest plant growth responses were generally recorded with Pisolithus isolates native from Australia (Burgess et al., 1994b).

Eucalypt AM symbioses are much less studied than its ECM symbioses. After Asai (1934) and Maeda (1954), it was only in the 1980s that they were really investigated (Malajczuk et al., 1981). Numerous works (Boudarga et al., 1990; Chen et al., 2000a; 2000b; Chilvers et al., 1987; Lapeyrie and Chilvers, 1985) showed that AM and ECM fungi could coexist not only on the same root system but even in the same root apex. The relative implication of each mycorrhizal type in the plant growth response is not clearly established (Chen et al., 2000a; 2000b; 2007; Lapeyrie and Chilvers, 1985). Nevertheless, a distinct plant response to both types of symbioses was observed along the plant development stage: arbuscular mycorrhizae generally are predominant on young saplings and ectomycorrhizae on older trees (de Mendonça Bellei et al., 1992; Oliveira et al., 1997). The biological processes leading to this mycorrhizal succession remain unknown (van der Heijden, 2001).

Outside their native areas, eucalypts are most commonly associated with ECM fungi belonging to the genera Pisolithus and Scleroderma (Bakshi, 1966; Garbaye et al., 1988; Mikola, 
1970; Thapar et al., 1967; Thoen and Ducousso, 1989). The question of the origin (indigenous or introduced) of these fungal genera is still under debate (Garbaye et al., 1988; Le Tacon et al., 1989). Hence, when using eucalypts as exotic tree species in a new plantation two strategies are eligible: either introducing selected ECM fungal strain that shared the same evolutionary history with their natural host, from Australia, or selecting efficient fungal strains among the indigenous fungi (Bâ, 1990; Garbaye et al., 1988). In a field trial in Congo, tree productivity of E. urophylla $\times$ E. kirtoniana hybrid trees inoculated with a North-American pinecompatible Pisolithus strain was $30 \%$ over the uninoculated controls (Garbaye et al., 1988). However, after one year of plantation, the inoculated strain was rapidly replaced by a local Scleroderma species, revealing the low compatibility of this North-American Pisolithus strain to eucalypts under local pedoclimatic conditions. Furthermore, in vitro experiments evidenced that an Australian Pisolithus, isolated from its natural E. urophylla host was much more aggressive in terms of root colonization than the North-American strain used in Congo (Lei et al., 1990; Malajczuk et al., 1990). This result shows the need of preliminary compatibility and efficiency tests with fungal strains isolated from the native area of the host tree, before field inoculations in a new area. For instance, field trials in China and Philippines (where indigenous fungi had poor compatibility with eucalypts) showed that $2 \mathrm{y}$ after inoculation with selected Australian Pisolithus and Scleroderma strains, the growth of eucalypts was improved 2.5 times over the uninoculated trees (Dell and Malajczuk, 1997). Moreover, local Pisolithus and Scleroderma strains were much less efficient than Australian strains, both in nursery and field experiments in China (Chen et al., 2006; Dell et al., 2002). Molecular tracing of Australian Pisolithus strains revealed that they survived and even fructified in the Chinese plantation soils over 3 y plantation (Dell et al., 2002).

It has been shown in axenic conditions that some scleroderma strains (e.g. S. dictyosporum and S. verrucosum) isolated from African native trees were not compatible with E. camaldulensis that is the most planted species in Senegal (Bâ, 1990) whereas fruitbodies of $S$. verrucosum and $S$. capense spontaneously occurred in E. camaldulensis plantations (Thoen and Ducousso, 1989). Nevertheless, regarding the intra-specific variation and distribution of African eucalypt-compatible scleroderms (Sanon et al., 1997), it is unclear whether these $S$. verrucosum constituted the same strain.

\section{CASUARINACEAE}

Members of Casuarinaceae family are actinorrhizal trees. They comprise 96 species including 59 Allocasuarina, $17 \mathrm{Ca}$ suarina, 2 Ceuthostoma and 18 Gymnostoma (Maggia and Bousquet, 1994). Their native areas range from Australia to South East Asia. Some species of Casuarina and Allocasuarina have been exported to the whole inter-tropical zone mainly as windbreaks or fuelwood; Casuarina equisetifolia, C. cunninghamiana and C. glauca, being dominant in plantations. In Senegal, thousands of hectares were planted with Casuarinaceae in the Niayes area and all along the littoral between Dakar and Saint-Louis to stabilize sand dunes (Dommergues et al., 1999). Within native area, Casuarinaceae are associated to a wide diversity of ECM fungi, some being common with Eucalypts (Reddell et al., 1991). Allocasuarina is the most ectotrophic genus with a wide diversity of fungal partners: about 20 fungal genera (e.g. Amanita, Elaphomyces, Pisolithus) were registered, while only few species (Scleroderma sp. and Thelephora sp.) were identified below Casuarina trees (Dell et al., 1994; Duponnois et al., 2003; Reddell et al., 1986; Thoen et al., 1990). Moreover, Casuarina does not systematically form ectomycorrhizae (Duponnois et al., 2003; Reddell et al., 1986). Nowadays, few data are available about the AM symbioses among Casuarinaceae, despite that these types of symbioses would be more common in the genus Casuarina (Duponnois et al., 2003; Reddell et al., 1986). A very particular feature of mycorrhizal symbioses has been described within some Neocaledonian species of Gymnostoma as "myconodules" hosting AM fungi belonging to the genus Glomus (Duhoux et al., 2001).

Casuarinaceae are also naturally associated with the nitrogen-fixing actinomycetous Frankia, which has been successfully inoculated to promote the growth of species used for the stabilisation of sand dunes in Senegal (Dommergues et al., 1999). This particular type of symbiosis may be responsible for the success of Casuarinaceae as exotics trees in the forest plantations in many countries. The three types of symbioses (ECM, AM and actinorrhizal symbiosis) have been shown to coexist on the same $C$. equisetifolia root system (Bâ et al., 1987), but their functional relevance remains unclear. Diem and Gauthier (1982) demonstrated that mycorrhization of C. equisetifolia saplings with Glomus mosseae improved the plant growth, Frankia nodulation and nitrogen fixation. Nevertheless, there is likely no report on mycorrhization of Casuarinaceae species beyond the nursery stage, despite its potential promoting effect on nitrogen fixation and plant growth.

\section{DIPTEROCARPACEAE}

Members of the Dipterocarpaceae are found in the tropics and predominantly in the rain forests of South East Asia. Their economic importance as timber is considerable. In Malaysia, they represent $70 \%$ of the timber production (Langenberger, 2006; Maruyama, 1997). Dipterocarpaceae often constitute pure forest stands in South East Asia, where the most common genera are Dipterocarpus, Hopea and Shorea. Some species, belonging to the genera Monotes and Marquesia, are naturally present in African forests, one genus (Pakaraimaeae) in South America, and one genus in the Seychelles ( $\mathrm{Va}$ teriopsis). Their mycorrhizal status is generally ectotrophic (Moyersoen, 2006; Nataranjan et al., 2005; Rivière et al., 2007; Singh, 1966; Smits, 1992; Tedersoo et al., 2007) and more rarely endotrophic (Aniwat, 1987). Their associated ECM fungi are highly diversified (Hong, 1979; Nataranjan et al., 2005; Watling and Lee, 1995). Six hundred and thirteen fungal species are known to fructify under dipterocarps: 
255 of which presumably are ECM fungi (e.g. S. verrucosum, Amanita hemibapha, Lactarius virescens) and 187 constitute new taxa (Watling and Lee, 1995). The genera Amanita, Russula and Phylloporus are among the most frequent both in natural stands and artificial plantations (Nataranjan et al., 2005), while scleroderms are the most represented fruiting taxa in Hopea spp. and Shorea spp. nurseries (Yazid et al., 1996). Recently, Sirikantaramas et al. (2003) using molecular tools evidenced that Thelephoraceae was one of the most common and abundant fungal families found on roots of Dipterocarpaceae.

So far, there is no pure cultivated strain from dipterocarp associated ECM fungi available in the literature (Yazid et al., 1994). This seriously limits the ECM synthesis experiments and controlled ectomycorrhization in nurseries and plantations. However, several features plead for a strong dependency of dipterocarp saplings to ECM fungi. Dipterocarp saplings exhibit a very poor growth without ECM partner, as it has been classically observed with pines (Smits et al., 1988). In addition, inoculations with crushed fruitbodies, excised ECM tips or spores contribute to a significant growth promotion of dipterocarp saplings (Lee, 1991; Lee and Alexander, 1994; Turjaman et al., 2005). Pure ECM fungal cultures would probably be much more beneficial and safer for sapling growth as the crushed fruitbodies and excised ECM tips may also be sources of contaminants (Garbaye, 1991). Furthermore, inoculation experiments in Malaysia using a pure allochtonous strain of $P$. tinctorius revealed a significant growth response with several Hopea species, but this Pisolithus strain was less competitive than native ECM fungi in plantation (Yazid et al., 1995).

The African dipterocarps are much less diversified than their Asian homologs. Monotes kerstingii is the only Western African dipterocarp which is encountered in association with Isoberlinia forming mixed stands (Aubreville, 1959; Sanon et al., 1997). M. kerstingii forms both AM and ECM symbioses (Sanon et al., 1997). Numerous ECM fruitbodies are detected under this tree species, some of them (e.g. S. verrucosum, Lactarius gymnocarpus) being also associated to Caesalpiniaceae (Sanon et al., 1997). In East Africa, dipterocarps are represented in both Monotes and Marquesia genera with several ECM species, such as Monotes elegans, M. africanus and Marquesia macroura (Alexander and Högberg, 1986; Högberg, 1982). Regarding the economic importance of dipterocarps, more works should be developed to elucidate their mycorrhizal dependency and potential benefits of nursery inoculation practices.

\section{LEGUMINOSAE}

Three subfamilies (Caesalpinioideae, Mimosoideae and Papilionoideae), some containing ECM tree species, constitute the Leguminosae family. In tropical Africa, the most exploited exotic leguminous tree species for their considerable economic interest as multipurpose in traditional agroforestry systems were gathered in Mimosoideae. This subfamily comprises about 2800 species mainly ligneous in semi-arid, subtropical or tropical zones of Africa, America and Australia. The Aca- cia genus is the most represented with about 1500 species, including three subgenera (Acacia, Aculeiferum, and Phyllodinae) that are distinguished on the molecular phylogeny of the chloroplast DNA sequences (Luckow et al., 2003). Subgenus Acacia contains several important and often emblematic African species (e.g. Acacia nilotica and A. tortilis). As Acacia, the subgenus Aculeiferum includes some important African species such as A. senegal. The third subgenus Phyllodinae contains Australian species of major economical importance as A. mangium, A. auriculiformis and A. crassicarpa. A. mangium is being extensively planted in South East Asia for pulp production (Cossalter, 1986). They are also appreciated in wet African countries as fuel or multipurpose woods (Galiana et al., 1996). In general, all species within Acacia are nodulated with nitrogen - fixing bacteria (Ducousso, 1991; Le Tacon et al., 1989), and are AM mycorrhized (Bâ and Guissou, 1996; Colonna et al., 1991; Duponnois et al., 2002). Generally, species that fit within the subgenus Phyllodinae are also ectomycorrhizal (Ducousso, 1991; Le Tacon et al., 1989). These different types of symbioses are often synergistic, the nitrogen-fixing symbioses having their highest efficiency only after inoculation with AM fungi (Cornet and Diem, 1982). In their native area, Australian acacias are spontaneously associated to the three symbionts (Warcup, 1980), but contrarily to eucalypts there is very few information about the diversity of their associated ECM fungi.

In Africa, the spontaneous ECM partners of Australian acacias would be restricted to the genus Pisolithus (Ducousso, 1990; Duponnois and Bâ, 1999). The origin of these compatible Pisolithus is still unclear, maybe fortuitously introduced. Nonetheless, several authors (Bâ, 1990; Bâ et al., 1994; Duponnois and Plenchette, 2003) detected true ectomycorrhizas between Australian acacias and native African ECM fungi in axenic conditions. For instance, ectomycorrhizal syntheses were obtained between A. holosericea and Scleroderma dictyosporum in axenic and glasshouse conditions (Bâ, 1990; Duponnois and Plenchette, 2003). Duponnois et al. (2005, 2007) observed in several experimental sites in Senegal, through inoculation trials with Pisolithus albus (strain IR100) (Tab. II), a significant growth promotion of A. holosericea and a reduction of negative effects during field transfer. $P$. albus was even able to develop its full life cycle as fruitbodies within the stand, 2 y after inoculation. In addition, P. albus was found to promote the efficiency of Bradyrhizobium inoculation and therefore growth response of $A$. holosericea (André et al., 2005). Some temperate ECM fungi such as Boletus and Suillus were also reported to colonize and promote the growth of A. auriculiformis, in Nigeria (Osonubi et al., 1991). In Madagascar, P. microcarpus strain 441 was found to persist on the roots of A. crassicarpa, another Australian species locally appreciated by farmers, while P. albus strain COI 007 was no longer detected after 19 months in the field (Ducousso et al., 2004).

Outside its native area, A. mangium inoculated with native Australian Bradyrhizobium strains generally gave excellent growth responses compared to the local spontaneous bacterial strains (Galiana et al., 1991; 1996). This was observed in African (Galiana et al., 1998; Prin et al., 2003) 
Table II. Field measurements of Acacia holosericea growth parameters in controlled ectomycorrhization trials conducted in Senegal. From Duponnois et al. (2007).

\begin{tabular}{|c|c|c|c|c|c|c|c|c|}
\hline \multirow[t]{2}{*}{$\overline{\text { Plantations }}$} & \multirow[t]{2}{*}{ Duration (months) } & \multicolumn{7}{|c|}{ Growth parameters } \\
\hline & & $\mathrm{SD}^{a}$ & $H$ & $H_{\text {est }}$ & LB & SBB & WB & $\mathrm{TB}$ \\
\hline$\overline{\text { EC7 }}$ & 30 & & & & & & & \\
\hline Control & & $9.9 \mathrm{a}^{b}$ & $4.39 \mathrm{a}$ & $4.49 \mathrm{a}$ & $13.2 \mathrm{a}$ & $11.8 \mathrm{a}$ & $17.9 \mathrm{a}$ & $42.6 \mathrm{a}$ \\
\hline P. albus IR100 & & $13.8 \mathrm{~b}$ & $4.93 \mathrm{~b}$ & $5.16 \mathrm{~b}$ & $27.4 \mathrm{~b}$ & $24.7 \mathrm{~b}$ & $42.5 \mathrm{~b}$ & $91.6 \mathrm{~b}$ \\
\hline EC8 & 18 & & & & & & & \\
\hline Control & & $2.7 \mathrm{a}$ & $2.49 \mathrm{a}$ & $2.9 \mathrm{a}$ & $0.77 \mathrm{a}$ & $0.64 \mathrm{a}$ & $0.60 \mathrm{a}$ & $2.11 \mathrm{a}$ \\
\hline P. albus IR100 & & $3.3 \mathrm{~b}$ & $2.82 \mathrm{~b}$ & $2.82 \mathrm{a}$ & $1.20 \mathrm{~b}$ & $1.00 \mathrm{~b}$ & $1.02 . b$ & $3.37 \mathrm{~b}$ \\
\hline EC9 & 18 & & & & & & & \\
\hline Control & & $2.6 \mathrm{a}$ & $2.43 \mathrm{a}$ & $2.55 \mathrm{a}$ & $0.71 \mathrm{a}$ & $0.59 \mathrm{a}$ & $0.55 \mathrm{a}$ & $1.94 \mathrm{a}$ \\
\hline P. albus IR100 & & $3.5 \mathrm{~b}$ & $2.87 \mathrm{~b}$ & $2.89 \mathrm{~b}$ & $1.36 \mathrm{~b}$ & $1.15 \mathrm{~b}$ & $1.19 \mathrm{~b}$ & $3.86 \mathrm{~b}$ \\
\hline EC10 & 18 & & & & & & & \\
\hline Control & & $2.5 \mathrm{a}$ & $2.37 \mathrm{a}$ & $2.51 \mathrm{a}$ & $0.65 \mathrm{a}$ & $0.54 \mathrm{a}$ & $0.49 \mathrm{a}$ & $1.77 \mathrm{a}$ \\
\hline P. albus IR100 & & $4.3 \mathrm{~b}$ & $3.15 \mathrm{~b}$ & $3.16 \mathrm{~b}$ & $2.14 \mathrm{~b}$ & $1.82 \mathrm{~b}$ & $2.03 \mathrm{~b}$ & $6.21 \mathrm{~b}$ \\
\hline EC11 & 18 & & & & & & & \\
\hline Control & & $5.7 \mathrm{a}$ & $3.63 \mathrm{a}$ & $3.55 \mathrm{a}$ & $3.96 \mathrm{a}$ & $3.42 \mathrm{a}$ & $4.24 \mathrm{a}$ & $11.89 \mathrm{a}$ \\
\hline P. albus IR100 & & $6.5 \mathrm{~b}$ & $3.81 \mathrm{~b}$ & $3.76 \mathrm{~b}$ & $5.28 \mathrm{~b}$ & $4.59 \mathrm{~b}$ & $5.97 \mathrm{~b}$ & $16.11 \mathrm{~b}$ \\
\hline EC13 & 18 & & & & & & & \\
\hline Control & & $3.1 \mathrm{a}$ & $2.60 \mathrm{a}$ & $2.75 \mathrm{a}$ & $1.04 \mathrm{a}$ & $0.88 \mathrm{a}$ & $0.86 \mathrm{a}$ & $2.91 \mathrm{a}$ \\
\hline P. albus IR100 & & $6.6 \mathrm{~b}$ & $3.81 \mathrm{~b}$ & $3.78 \mathrm{~b}$ & $5.46 \mathrm{~b}$ & $4.75 \mathrm{~b}$ & $6.21 \mathrm{~b}$ & $16.68 \mathrm{~b}$ \\
\hline
\end{tabular}

${ }^{a} \mathrm{SD}$ : stem diameter $(\mathrm{cm}) ; H$ : height $(\mathrm{m}) ; H_{\mathrm{est}}$ : estimated height $(\mathrm{m})$; LB: leaf biomass $(\mathrm{kg}$ per tree); SBB: small branches biomass $(\mathrm{kg}$ per tree); WB: wood biomass (kg per tree); TB: total aboveground biomass ( $\mathrm{kg}$ per tree).

${ }^{b}$ For each experiment, data in the same column followed by the same letter are not significantly different according to the least significant difference (LSD) multiple range test $(P<0.05)$.

and Asian countries (Frémont et al., 1999; Martin-Laurent et al., 1999). Inoculation of A. mangium with AM fungi was less convincing probably due to the presence of native efficient strains (de la Cruz and Yantasath, 1993). Concerning ECM symbioses few data are available on spontaneous fungal associates of A. mangium. Only Thelephora ramarioides and Clavaria spp. were reported on A. mangium in Malaysia (Lee, 1990) and Philippines (Anino 1992), respectively. In West Africa, Pisolithus was reported in Australian acacias plantations (Ducousso, 1990; Duponnois et al., 2000). Several studies (Duponnois and Bâ, 1999; Duponnois and Plenchette, 2003) showed that the efficiency of the associations between Acacias and Pisolithus generally depends on soluble P contents in soil.

\section{CONCLUSION}

The works reported in this review pointed out the importance of root symbionts (mycorrhizal fungi and nitrogen fixing bacteria) in establishment and growth of exotic tree species in tropical Africa. Indeed, it was initially observed that exotic pines were unable to establish in the tropics unless symbiotic compatible ECM fungi were introduced (Hacskaylo, 1971). These tropical pines are in fact mostly associated with $R h i$ - zopogon spp., and Suillus spp., members of the suilloid group, a monophyletic lineage which includes ECM fungi that exhibit high host specificity (Bruns et al., 2002) and are rarely encountered in tropical Africa (Rivière et al., 2007). Unlike tropical pines, eucalypts are associated with highly diversified ECM fungi. Different growth responses of eucalypts to Pisolithus inoculation were obtained depending on the origins of fungal isolates, the best results being generally observed with isolates sharing the same evolutionary history with their host. This illustrates the importance of taking into account the co-evolution of symbiotic partners in the selection of good symbionts for improvement of timber productivity.

The exotic tree species surveyed for their response to inoculation with selected fungal strains displayed significant mycorrhizal dependencies. Nevertheless, in a new habitat, competition may occur between introduced fungal strains and local soil microorganisms and therefore cuts down the beneficial effect of inoculation on growth of these exotic tree species. In this context, it appears difficult to predict the response of exotic tree species to inoculation in a new habitat without testing the efficiency and competitiveness of selected symbiotic partners under local soil constraints.

On the other hand, exclude Pinaceae which were colonized by only ECM fungi, all exotic tree species presented here are associated with either both ECM and AM fungi (e.g. 
Eucalyptus), or sometimes with three coexisting symbionts (e.g. Casuarina, Acacia) that are well adapted to the abiotic and biotic factors of their natural habitats. Nevertheless, little is known about the interaction of these different symbionts on their host trees and how they benefit its growth. Hence, the new challenge is to elucidate the relative implication of each symbiont in their host growth promotion for their better exploitation in sylviculture and reforestation.

\section{REFERENCES}

Anino E.O., 1992. Natural ecto-mycorrhiza of Acacia mangium. Nitrogen Fixing Tree Res. Rep. 10: 96.

Aggangan N.S., Dell B., and Malajczuk N., 1996a. Effects of soil pH on the ectomycorrhizal response of Eucalyptus urophylla seedlings. New Phytol. 134: 539-546.

Aggangan N.S., Dell B., Malajczuk N., and De La Cruz R.E., 1996b. Soil fumigation and phosphorus supply affect the formation of PisolithusEucalyptus urophylla ectomycorrhizas in two acid Philippine soils. Plant Soil 180: 259-266.

Alexander I.J. and Högberg P., 1986. Ectomycorrhizas of tropical angiosperm trees. New Phytol. 102: 541-549.

Aubreville A., 1959. La flore forestière de la Côte d'Ivoire. Publication CTFT N $^{\circ} 15$ (3 volumes), Nogent-sur-Marne, France.

André S., Galiana A., Le Roux C., Prin Y., Neyra M., and Duponnois R., 2005. Ectomycorrhizal symbiosis enhanced the efficiency of two Bradyrhizobium inoculated on Acacia holosericea plant growth. Mycorrhiza 15: 357-364.

Aniwat C., 1987. Mycorrhizal survey of dry-deciduous and semievergreen dipterocarp forest ecosystems in Thailand [C]. In: Kostermsns A.J.C.H. (Ed.), Proceedings of the Third Round Table Conference on Dipterocarps, Mulawarman University, Indonesia, pp. 81-103.

Asai M.T., 1934. Uber das Vorkommen und die Bedeutung der Wurzelpilze in den Landpflanzen. Jpn. J. Bot. 1: 107-150.

Bâ A.M., Sougoufara B., and Thoen D., 1987. The triple symbiosis of Casuarina equisetifolia in Senegal. In: Sylvia D.M., Hung L.L., Graham J.H. (Eds.), Mycorrhizae in the next decade, Gainesville, USA, University of Florida, p. 121.

Bâ A.M., 1990. Contribution à l'étude de la symbiose ectomycorhizienne chez deux essences forestières d'Afrique intertropicale: Afzelia africana et Uapaca guineensis. Ph.D. thesis, University of Montpellier II, France.

Bâ A.M., Garbaye J., and Dexheimer J., 1994. The influence of culture conditions on mycorrhiza formation between the ectomycorrhizal fungus Pisolithus sp. and Afzelia africana seedlings. Mycorrhiza 4: 121-129.

Bâ A.M. and Guissou T., 1996. Rock phosphate and mycorrhizas effects on growth and nutrient uptake of Faidherbia albida (Del.) in an alkaline sandy soil. Agrofor. Syst. 34: 129-137.

Bakshi B.K., 1966. Mycorrhiza in eucalypts in India. Indian For. 92: 19-20.

Boudarga K., Lapeyrie F., and Dexheimer J., 1990. A technique for dual vesicular-arbuscular endomycorrhizal/ectomycorrhizal infection of Eucalyptus in vitro. New Phytol. 114: 73-76.

Bruns T.D., Bidartondo M.I., and Taylor D.L., 2002. Host specificity in ectomycorrhizal communities: what do the exceptions tell us? Integr. Comp. Biol. 42: 352-359.

Burgess T., Malajczuk N., and Dell B., 1994a. Variation in Pisolithus based on basidiocarp and basidiosporc morphology, culture characteristics and polypeptide analysis using ID-SDS PAGE. Mycol. Res. 99: 1-13.

Burgess T., Dell B., and Malajczuk, N., 1994b. Variation in mycorrhizal development and growth stimulation by 20 Pisolithus isolates inocu- lated on to Eucalyptus grandis W. Hill ex Maiden. New Phytol. 127: 731-739.

Castellano M.A. and Bougher N.L., 1994. Consideration of the taxonomy and biodiversity of Australian ectomycorrhizal fungi. Plant Soil 159: $37-46$.

Chen Y.L., Gong M.Q., Xu D.P., Zhong C.L., Wang F.Z., and Chen Y., 2000a. Screening and inoculant efficacy of Australian ectomycorrhizal fungi on Eucalyptus urophylla in field. For. Res. 13: 569-576.

Chen Y.L., Brundrett M.C., and Dell B., 2000b. Effects of ectomycorrhizas and vesicular-arbuscular mycorrhizas, alone or in competition, on root colonization and growth of Eucalyptus globulus and E. urophylla. New Phytol. 146: 545-556.

Chen Y.L., Kang L.H., and Dell B., 2006. Inoculation of Eucalyptus urophylla with spores of Scleroderma in a nursery in south China: comparison of field soil and potting mix. For. Ecol. Manage. 222: 439-449.

Chen Y.L., Liu S., and Dell B., 2007. Mycorrhizal status of Eucalyptus plantations in South China and implications for management. Mycorrhiza 17: 527-535.

Chilvers G.A., 1972. Host range of some eucalypt mycorrhizal fungi. Aust. J. Bot. 21: 103-111.

Chilvers G.A., Lapeyrie F., and Horan D.P., 1987. Ectomycorrhizal vs. endomycorrhizal fungi within the same root system. New Phytol. 107, 441-448.

Colonna J.P., Thoen D., Ducousso M., and Badji S., 1991. Comparative effects of Glomus mosseae and P fertilized on foliar mineral composition of Acacia senegal seedlings inoculated with Rhizobium, Mycorrhiza 1: 35-38.

Cornet F. and Diem H.G., 1982. Étude comparative de l'ef?cacité des souches de Rhizobium isolées de sols du Sénégal et effet de la double symbiose Rhizobium - Glomus mosseae sur la croissance de Acacia holosericea et A. raddiana. Bois et Forêts des Tropiques 198: 3-15.

Cossalter C., 1986. Introducing Australian Acacias in dry, tropical Africa. In: Turnbull J.W. (Ed.), Australian acacias in developping countries. Proceedings of an International Workshop at the Forestry Training Center, Gympie, Australia 1986. ACIAR, Camberra, 1986, pp. 118122.

De la Cruz R.E. and Yantasath K., 1993. Symbiotic associations. In: Kamis, A., Taylor, D. (Eds.), Acacia mangium, Growing and Utilization. Winrock International and The Food and Agriculture Organization of the United Nations, Bangkok, Thailand, pp. 101111.

De Mendonça Bellei M., Garbaye J., and Gil M., 1992. Mycorrhizal succession in young Eucalyptus viminalis plantations in Santa Catarina (southern Brazil). For. Ecol. Manage. 54, 205-13.

Dell B., Malajczuk N., Bougher N.L., and Thomson G., 1994. Development and function of Pisolithus and Scleroderma ectomycorrhizas formed in vitro with Allocasuarina, Casuarina and Eucalyptus. Mycorrhiza 5: 129-138.

Dell B. and Malajczuk N., 1997. L'inoculation des eucalyptus introduits en Asie avec des champignons ectomycorhiziens australiens en vue d'augmenter la productivité des plantations. Rev. For. Fr. 49: 174184.

Dell B., Malajczuk N., and Dunstan, W.A., 2002. Persistence of some Australian Pisolithus species introduced into eucalypt plantations in China. For. Ecol. Manage. 169: 271-281.

Delwaulle J.C., 1978. Plantations forestières en Afrique tropicale sèche. Techniques et espèces à utiliser. Bois et Forêts des Tropiques, 182: $3-18$.

Delwaulle J.C., Garbaye J., and Okombi G., 1982. Stimulation de la croissance initiale de Pinus caribaea Morelet dans une plantation du Congo par le contrôle de la mycorhization. Bois et Forêts des Tropiques 196: 25-32.

Delwaulle J.C., Diangana D., and Garbaye J., 1987. Augmentation de la production du pin des Caraïbes dans la région côtière du Congo par l'introduction du champignon Pisolithus tinctorius. Rev. For. Fr. 39: 409-417. 
Diem H.G. and Gauthier D., 1982. Effet de l'infection endomycorhizienne (Glomus mosseae) sur la nodulation et la croissance de Casuarina equisetifolia. C.R. Acad. Sci. (Paris) 294: 215-218.

Dommergues Y., Duhoux E., and Diem H.G., 1999. Les arbres fixateurs d'azote : Caractéristiques fondamentales et rôle dans l'aménagement des écosystèmes méditerranéens et tropicaux. Editions Lavoisier. $498 \mathrm{p}$.

Ducousso M., 1991. Importance des symbioses racinaires pour l'utilisation des acacias en Afrique de l'Ouest. Thèse de Doctorat. Université Claude Bernard, Lyon I, Nogent-sur-Marne, France, Dakar, Sénégal, Cirad/Isra, 205 p.

Ducousso M., Galiana A., Chaix G., and Prin Y., 2004. Relative infectivity of two Pisolithus spp. strains inoculated to the nitrogen-fixing legume tree Acacia crassicarpa A. Cunn. Ex Benth. in a field experiment in Madagascar. Eur. J. Soil Biol. 40: 105-111.

Duhoux E., Rinaudo G., Diem H.G., Auguy F., Fernandez D., Bogusz D., Franche C., and Dommergues Y., 2001. Angiosperm Gymnostoma trees produce root nodules colonised by arbuscular mycorrhial fungi related to Glomus. New Phytol. 149: 115-125.

Duponnois R. and Bâ A.M., 1999. Growth stimulation of Acacia mangium Willd by Pisolithus sp. in some senegalese soils. For. Ecol. Manage. 119: 209-215.

Duponnois R., Founoune, H., Bâ A.M., Plenchette C., EL Jaafari S., Neyra M., and Ducousso, M., 2000. Ectomycorrhization of Acacia holosericea A. Cunn. ex G. Don by Pisolithus spp. in Senegal: effect on plant growth and on the root-knot nematode Meloidogyne javanica. Ann. For. Sci. 57: 345-350.

Duponnois R., Founoune H., and Lesueur D., 2002. Influence of the controlled dual ectomycorrhizal and rhizobal symbiosis on the growth of Acacia mangium provenances, the indigenous symbiotic microflora and the structure of plant parasitic nematode communities. Geoderma 109: 85-102.

Duponnois R. and Plenchette C., 2003. A mycorrhiza helper bacterium (MHB) enhances ectomycorrhizal and endomycorrhizal symbiosis of Australian Acacia species. Mycorrhiza 13: 85-91.

Duponnois R., Diédhiou S., Chotte J.-L., and Sy M.O., 2003. Relative importance of the endomycorrhizal and/or ectomycorrhizal associations in Allocasuarina and Casuarina genera. Can. J. Microbiol. 49: 281-287.

Duponnois R., Founoune H., Masse D., and Pontanier R., 2005. Inoculation of Acacia holosericea with ectomycorrhizal fungi in a semi-arid site in Senegal: growth response and influences on the mycorrhizal soil infectivity after 2 years plantation. For. Ecol. Manage. 207: 351-362.

Duponnois R., Plenchette C., Prin Y., Ducousso M., Kisa M., Bâ A.M., and Galiana A., 2007. Use of mycorrhizal inoculation to improve reafforestation process with Australian Acacia in Sahelian ecozones. Ecol. Eng. 29: 105-112.

Frémont M., Prin Y., Chauvière M., Diem H.G., Pwee K.H., and Tan T.K., 1999. A comparison of Bradyrhizobium strains using molecular, cultural and field studies. Plant Sci. 141: 81-91.

Galiana A., Tibok A., and Duhoux E., 1991. Nitrogen-fixing potential of rnicropropa-gated clones of Acacia mangium inoculated with different Bradyrhizobium spp. strains. Plant Soil 135: 161-166.

Galiana A., N'Guessan Kanga A., Gnahoua G.M., Balle P., Dupuy B., Domenach A.M., and Mallet B., 1996. Fixation de l'azote chez Acacia mangium en plantation. Bois et Forêts des Tropiques 249: $51-62$.

Galiana A., Gnahoua G.M., Chaumont J., Lesueur D., Prin Y., and Mallet B., 1998. Improvement of nitrogen fixation in Acacia mangium through inoculation with rhizobium. Agrofor. Syst. 40: 297-307.

Garbaye J., 1991. Utilisation des mycorhizes en sylviculture. In: Strullu D.G. (Ed.), Les mycorhizes des arbres et des plantes cultivées, Technique et Documentation Lavoisier, Paris, pp. 197-248.

Garbaye J., Delwaulle J.C., and Diangana D., 1988. Growth response of eucalypts to mycorrhizal inoculation in the Congo. For. Ecol. Manage. 24, 151-157.
Hacskaylo E., 1971. Mycorrhizae, US Government Printing Office, Washington, DC, $255 \mathrm{p}$.

Högberg P., 1982. Mycorrhizal associations in some woodland and forest trees and shrubs in Tanzania. New Phytol. 92: 407-415.

Hong L.T., 1979. A note on dipterocarp mycorrhizal fungi. Malays. For. 42: $280-283$.

Kabre A., 1982. Mycorhization de Pinus caribaea (Morelet) var. Hondurensis dans différents sols du Sénégal. Thèse de doctorat, Université Nancy I, Nancy.

Khasa P.D. and Bousquet J., 1995. Développement d'un programme intégré d'amélioration génétique du Racosperma spp. pour le reboisement de terres marginales zaïroises. Sécheresse 6: 281-288.

Lamhamedi M.S. and Fortin J.A., 1991. Genetic variations of ectomycorrhizal fungi: extramatrical phase of Pisolithus spp. Can. J. Bot. 69: 1927-1934.

Langenberger G., 2006. Habitat distribution of dipterocarp species in the Leyte Cordillera: an indicator for species - site suitability in local reforestation programs. Ann. For. Sci. 63: 149-156.

Lapeyrie F.F. and Chilvers G.A., 1985. An endomycorrhizaectomycorrhiza succession associated with enhanced growth by Eucalyptus dumosa seedlings planted in a calcareous soil. New Phytol. 100: 93-104.

Lee S.S., 1990. The mycorrhizal association of the Dipterocarpaceae in the tropical rain forests of Malaysia. AMBIO 19: 383-385.

Lee S.S., 1991. An unusual ectomycorrhizal-like structure from Shorea leprosula (Dipterocarpaceae). In: Soerianegara I., Tjitrosomo S.S., Umaly R.C., Umboh I. (Eds.), Proceedings of the Fourth Round Table Conference on Dipterocarps, 12-15 December 1989. Bogor. BIOTROP Sp. Publ. No. 41, pp. 141-145.

Lee S.S. and Alexander I.J., 1994. The response of seedlings of two dipterocarp species to nutrient additions and ectomycorrhizal infection. Plant Soil 163: 299-306.

Le Tacon F., Garbaye J., Bâ A.M., Beddiar A.F., Diagne O., and Diem H.G., 1989. Importance des symbioses racinaires pour les arbres forestiers en zone tropicale sèche et en zone tropicale humide. In: Trees for development in Sub-Saharian Africa, ICRAF HQ, Nairobi, Kenya, pp. 302-318.

Lei J., Lapeyrie F., Malajczuk N., and Dexheimer J., 1990. Infectivity of isolates of Pisolithus tinctorius (Pers) Coker and Couch on roots of Eucalyptus urophylla ST Blake in vitro. New Phytol. 116: 115-122.

Luckow M., Miller J.T., Murphy D.J., and Livshultz T., 2003. A phylogenetic analysis of the Mimosoideae (Leguminosae) based on chloroplast DNA sequence data. In: Klitgaard B.B. and Bruneau A. (Eds.), Advances in legumes systematics, Part 10, Higher level systematics, Royal Botanic Gardens, Kew, UK, pp. 197-220.

Maeda M., 1954. The meaning of mycorrhiza in regard to systematic botany. Kumamoto J. Sci.: 57-84.

Maggia L. and Bousquet J., 1994. Molecular phylogeny of the actinorrhizal Hamamelidae and relationships with host promiscuity towards Frankia. Mol. Ecol. 3: 459-467.

Malajczuk N., Linderman R., Kough J., and Trappe J.M., 1981. Presence of vesicular-arbuscular mycorrhizae in Eucalyptus sp. and Acacia sp., and their absence in Banksia sp. after inoculation with Glomus fasciculatus. New Phytol. 87: 567-572.

Malajczuk N., Molina R., and Trappe J.M., 1982. Ectomycorrhiza formation in Eucalyptus. I. Pure culture synthesis, host specificity and mycorrhizal compatibility with Pinus radiata. New Phytol. 91: 467482.

Malajczuk N., Lapeyrie F., and Garbaye J., 1990. Infectivity of pine and eucalypt isolates of Pisolithus tinctorius on roots of Eucalyptus urophylla in vitro. New Phytol. 114: 627-631.

Martin F., Diez J., Dell B., and Delaruelle C., 2002. Phylogeography of the ectomycorrhizal Pisolithus species as inferred from nuclear ribosomal DNA ITS sequences. New Phytol. 153: 345-357.

Martin-Laurent F., Lee S.K., Tham F.Y., Jie H., and Diem H.G., 1999. Aeroponic production of Acacia mangium saplings inoculated with 
AM fungi for reforestation in the tropics. For. Ecol. Manage. 122: 199-207.

Maruyama Y., 1997. Ecophysiological study on adaptability of dipterocarps to environmental stress (In Japanese). Trop. For. 40: 45-54.

Marx D.H., 1977. Tree host range and world distribution of the ectomycorrhizal fungus Pisolithus tinctorius. Can. J. Microbiol. 23: 217-223.

Marx D.H., 1980. Ectomycorrhizal fungus inoculations: a tool for improving forestation practices. In: Mikola P. (Ed.), Tropical mycorrhiza research, Oxford University Press, New York, USA, pp. 13-71.

Marx D.H., Hedin A., and Toe S.F.P., 1985. Field performance of Pinus caribaea var. hondurensis seedlings with specific ectomycorrhizae and fertilizer after three years on a savanna site in Liberia. For. Ecol. Manage. 13: 1-25.

Mikola P., 1970. Mycorrhizal inoculation in afforestation. Int. Rev. For. Res. 3: 123-196.

Molina R. and Trappe J.M., 1994. Biology of the ectomycorrhizal genus, Rhizopogon. 1. Host association, host specificity and pure culture synthesis. New Phytol. 126: 653-675.

Momoh Z.O. and Gbadegesin R.A., 1980. Field performance of Pisolithus tinctorius as a mycorrhizal fungus of pines in Nigeria. In: Mikola P. (Ed.), Tropical mycorrhiza research, Oxford University Press, New York, USA, pp. 72-79.

Moyersoen B., 2006. Pakaraimaeae dipterocarpacea is ectomycorrhizal, indicating an ancient Gondwanaland origin for the ectomycorrhizal habit in Dipetrocarpaceae. New Phytol. 172: 753-762.

Natarajan K., Senthilarasu G., Kumaresan V., and Rivière T., 2005. Diversity in ectomycorrhizal fungi of a dipterocarp forest in Western Ghats. Curr. Sci. 88: 1893-1895.

Ofosu-Asiedu A., 1980. Field performance of Pinus caribaea inoculated with pure cultures of four mycorrhizal fungi. In: Mikola P. (Ed.), Tropical mycorrhiza research, Clarendon Press, 270 p.

Oliveira V.L., Schmidt V.D.B., and Bellei M.M., 1997. Patterns of arbuscular- and ecto- mycorrhizal colonization of Eucalyptus dunnii in southern Brazil. Ann. For. Sci. 54: 473-481.

Osonubi O., Mulongoy K., Awotoye O.O., Atayese M.O., and Okali D.U.U., 1991. Effects of ectomycorrhizal and vesicular-arbuscular mycorrhizal fungi on drought tolerance of four leguminous woody seedlings. Plant Soil 136: 131-143.

Prin Y., Galiana A., Le Roux C., Méléard B., Razafimaharo V., Ducousso M., and Chaix G., 2003. Molecular tracing of Bradyrhizobium strains helps to correctly interpret Acacia mangium response to inoculation in a reforestation experiment in Madagascar. Biol. Fertil. Soils 37: 64-69.

Pryor L.D. and Johnson L.A.S., 1971. A classification of the eucalypts, Aust. Nat. Univ., Canberra, 102 p.

Reddell P., Foster R.C., and Bowen G.D., 1986. The effects of sodium chloride on growth and nitrogen fixation in Casuarina obese Miq. New Phytol. 102: 397-408.

Reddell P., Diem H.G., and Dommergues Y.R., 1991. Use of actinorrhizal plants in arid and semi-arid environments. In: Skujins J. (Ed.), Semiarid lands and deserts. Soil Resources and Reclamation, Marcel Dekker, New York, pp. 469-485.

Rincón A., de Felipe M.R., and Fernández-Pascual M., 2007. Inoculation of Pinus halepensis Mill. with selected ectomycorrhizal fungi improves seedling establishment 2 years after planting in a degraded gypsum soil. Mycorrhiza 18: 23-32.

Rivière T., Diédhiou A.G., Diabaté M., Senthilarasu G., Natarajan K., Verbeken A., Buyck B., Dreyfus B., Béna G., and Bâ A.M., 2007. Genetic diversity of ectomycorrhizal Basidiomycetes from African and Indian tropical rain forests. Mycorrhiza 17: 415-428.

Sanon K.B., Bâ A.M., and Dexheimer J., 1997. Mycorrhizal status of some fungi fruiting beneath indigenous trees in Burkina Faso. For. Ecol. Manage. 98: 61-69.

Singh K.G., 1966. Ectotrophic mycorrhiza in equatorial rain forests. Malays. Forester 29: 13-18.

Sirikintaramas S., Sugioka N., Lee S.S., Mohamed L.A., Lee H.S., Szmidt A.E., and Yamazaki T., 2003. Molecular identification of ectomycorrhizal fungi associated with Dipterocarpaceae. Tropics 13: 69-77.

Smith S. and Read J., 2008. Mycorrhizal symbiosis, 3rd ed. Academic Press, $800 \mathrm{p}$.

Smits W.T.M., 1992. Mycorrhizal studies in dipterocarp forests in Indonesia. In: Read D.J., Lewis D.H., Fitter A.H., Alexander I.J. (Eds.), Mycorrhizas in ecosystems, Cambridge, pp. 283-292.

Tedersoo L., Suvi T., Beaver K., and Köljalg U., 2007. Ectomycorrhizal fungi of the Seychelles: diversity patterns and host shifts from the native Vateriopsis seychellarum (Dipterocarpaceae) and Intsia bijuga (Caesalpiniaceae) to the introduced Eucalyptus robusta (Myrtaceae), but not Pinus caribae (Pinaceae). New Phytol. 175: 321-333.

Thapar H.S., Singh B., and Bakshi B.K., 1967. Mycorrhizae in Eucalyptus. Indian For. 93: 756-759.

Thoen D. and Ducousso M., 1989. Mycorrhizal habit and sclerogenesis of Phlepobus sudanicus (Gyrodontaceae) in Senegal. Agric. Ecosyst. Environ 28: 519-523.

Thoen D., Sougoufara B., and Dommergues Y., 1990. In vitro mycorrhization of Casuarina and Allocasuarina species by Pisolithus isolates. Can. J. Bot. 68: 2537-2542.

Turjaman M., Tamai Y., Segah H., Limin S.H., Cha J.Y., Osaki M., and Tawaraya K., 2005. Inoculation with the ectomycorrhizal fungi Pisolithus arhizus and Scleroderma sp. improves early growth of Shorea pinanga nursery seedlings. New For. 30: 67-73.

van der Heijden M.G.A., 2001. Differential benefits of arbuscular mycorrhizal and ectomycorrhizal infection of Salix repens. Mycorrhiza 10: 185-193.

Warcup J.H., 1980. Ectomycorrhizal associations of Australian indigenous plants. New Phytol. 85: 531-535.

Watling R. and Lee S.S., 1995. Ectomycorrhizal fungi associated with members of the Dipterocarpaceae in Peninsular Malaysia. J. Trop. For. Sci. 7: 657-669.

Yazid M.S., Lee S.S., and Lapeyrie F., 1994. Growth stimulation of Hopea spp. (Dipterocarpaceae) seedlings following mycorrhizal inoculation with an exotic strain of Pisolithus tinctorius. For. Ecol. Manage. 67: 339-343.

Yazid M.S., Lee S.S., and Lapeyrie F., 1996. Mycorrhizal Inoculation of Hopea odorata (Dipterocarpaceae) in the nursery. J. Trop. For. Sci. 9: 276-278

Zhu J., Li F., Xu M., Kang H., and Wu X., 2008. The role of ectomycorrhizal fungi in alleviating pine decline in semiarid sandy soil of northern China: an experimental approach. Ann. For. Sci. 65: 304. 